\title{
Identification of Human Herpesvirus 8 Sequences in Conjunctiva Intraepithelial Neoplasia and Squamous Cell Carcinoma of Ugandan Patients
}

\author{
Noemy Starita, ${ }^{1}$ Clorinda Annunziata, ${ }^{1}$ Keith M. Waddell, ${ }^{2}$ \\ Luigi Buonaguro, ${ }^{1}$ Franco M. Buonaguro, ${ }^{1}$ and Maria Lina Tornesello ${ }^{1}$ \\ ${ }^{1}$ Molecular Biology and Viral Oncology, Istituto Nazionale Tumori "Fondazione G Pascale", IRCCS, 80131 Naples, Italy \\ ${ }^{2}$ Departments of Ophthalmology and Paediatrics, Mbarara University of Science and Technology, P.O. Box 1410, Mbarara, Uganda
}

Correspondence should be addressed to Maria Lina Tornesello; ml.tornesello@istitutotumori.na.it

Received 22 April 2015; Revised 18 June 2015; Accepted 28 June 2015

Academic Editor: Yanjin Zhang

Copyright (c) 2015 Noemy Starita et al. This is an open access article distributed under the Creative Commons Attribution License, which permits unrestricted use, distribution, and reproduction in any medium, provided the original work is properly cited.

The incidence of squamous cell carcinoma of the conjunctiva is particularly high in sub-Saharan Africa with temporal trends similar to those of Kaposi sarcoma (KS). Human herpesvirus type 8 (HHV8), has not yet been investigated in conjunctiva tumors. In this study biopsies and PBMCs of conjunctiva neoplasia patients along with nonneoplastic conjunctiva tissues have been analyzed for HHV8 sequences by PCR targeting ORF26. All amplimers were subjected to nucleotide sequencing followed by phylogenetic analysis. HHV8 DNA has been identified in 12 out of 48 (25\%) HIV-positive, and in 2 out of 24 (8.3\%) HIV-negative conjunctiva neoplastic tissues and in 4 out of 33 (12.1\%) PBMC samples from conjunctiva neoplasia diseased patients as well as in 4 out of 60 $(6.7 \%)$ nontumor conjunctiva tissues. The viral load ranged from 1 to 400 copies $/ 10^{5}$ cells. Phylogenetic analysis showed that the majority of HHV8 ORF26 amplimers clustered with subtypes $\mathrm{R}(n=11)$ and $\mathrm{B} 2(n=6)$. This variant distribution is in agreement with that of HHV8 variants previously identified in Ugandan KS cases. The presence of HHV8 in conjunctiva tumors from HIVpositive patients warrants further studies to test whether HHV8 products released by infected cells may have paracrine effects on the growth of conjunctiva lesions.

\section{Introduction}

The incidence of squamous cell carcinoma of the conjunctiva (CSCC) has shown a dramatic increase in the subSaharan African populations during the HIV/AIDS era [15]. In Uganda the incidence has increased more than tenfold between 1960-1971 and 1995-1997 and has remained high during the period 1991-2010 [6]. Similarly, a 10-fold increase in the incidence of conjunctival carcinoma has been reported in Harare, Zimbabwe, during the period 1991-2004 [3]. This finding supported the hypothesis that HIV-related immune suppression could facilitate the oncogenic process of other oncogenic agents infecting the conjunctival mucosa. Several viruses have been searched in HIV-positive and HIV-negative conjunctival neoplasia, including cutaneous and mucosal human papillomaviruses [7-9], but the etiologic mechanism of such tumor remains still unclear.
Human herpesvirus type 8 (HHV8) is the causal agent of all clinical forms of Kaposi sarcoma, of two B-cell tumors, namely, primary effusion lymphoma and multicentric Castleman disease, and the recently described HHV8 inflammatory cytokine syndrome [10-14]. Kaposi sarcoma is a vascular lesion which frequently develops in mucocutaneous sites including the ocular surface [15-17]. Indeed, Kaposi sarcoma of the conjunctiva and ocular adnexa were observed in approximately $5 \%$ of HIV/AIDS patients before HAART [18].

The HHV8 encodes several homologues of human proteins, such as viral G protein-coupled receptor (vGPCR), viral interferon regulatory factors 1-4 (vIRF 1-4), viral interleukin 6 (vIL-6), viral Fas-associated death domainlike IL-1-converting enzyme inhibitory protein (vFLIP), and vBCL2 that are able to promote cell survival, immune evasion, angiogenesis, and inflammation [19]. Moreover, HHV8 vGPCR induces secretion of vascular endothelial 
growth factor (VEGF), IL-6, and platelet derived growth factor (PDGF) which, together with the vIL-6 and vFLIP, deregulate via autocrine and paracrine mechanisms the proliferation and apoptosis of uninfected cells surrounding those harboring replicating virus $[20,21]$. Moreover, in the HHV8 inflammatory cytokine syndrome the symptoms are associated with excess lytic activation of the virus, elevated levels of HHV8 vIL-6, IL-6, and viral loads [22].

The HHV8 has been shown to infect a variety of cells including endothelial, epithelial, and B cells as well as monocytes and CD34+ hematopoietic progenitor stem cells $[23,24]$. The viral DNA has been found in normal skin, plasma, and PBMCs of a significant fraction of Kaposi sarcoma patients [25]. In Uganda, where Kaposi sarcoma is endemic, HHV8 in plasma was detected in $8.7 \%$ of the general population [26]. Among HIV-positive patients with no diagnosis of Kaposi sarcoma, HHV8 DNA has been identified in PBMCs in $13 \%$ of patients in association with lower CD4+ cell counts and higher plasma HIV RNA [27].

DNA sequences of HHV8 have been also detected in nonKaposi skin lesions of transplant recipients, in pemphigus vulgaris and mycosis fungoides lesions, in angiosarcomas, and in angiolymphoid hyperplasia [28]. No study systematically searched for HHV8 DNA in conjunctival neoplastic lesions.

This study aimed to analyze the prevalence of HHV8 DNA in conjunctival neoplasia biopsies at different stages of malignancy, including conjunctival intraepithelial lesions grades 1 to 3 (CIN1, -2 , or -3 ), in invasive conjunctival squamous cell carcinoma (CSCC) and in PBMCs from conjunctiva neoplasia HIV-positive and HIV-negative patients as well as in conjunctival tissues from healthy control subjects.

\section{Materials and Methods}

2.1. Patients and Specimens. Conjunctival biopsies from 72 patients with conjunctival neoplasia from 60 conjunctiva subjects with nonneoplastic were obtained at seven countrywide eye clinics in Southern Uganda from all subjects who gave informed consent to participate in the study. Peripheral blood mononuclear cells (PBMCs) obtained from 33 conjunctiva neoplasia patients, whose surgical biopsies were not available, were also included in the study. The study protocol was approved by the local ethical review board. All cases and controls were previously characterized in terms of histology, DNA quality, HIV serology, and cutaneous and mucosal HPV DNA positivity [7, 29]. DNA extraction was performed with similar procedures for both types of samples (frozen biopsies and PBMCs). Briefly samples were digested with proteinase $\mathrm{K}\left(150 \mu \mathrm{g} / \mathrm{mL}\right.$ at $60^{\circ} \mathrm{C}$ for $\left.30 \mathrm{~min}\right)$ in lysis buffer (10 mM Tris- $\mathrm{HCl} \mathrm{pH}$ 7.6, $5 \mathrm{mM}$ EDTA, $150 \mathrm{mM}$ $\mathrm{NaCl}$, and $1 \% \mathrm{SDS}$ ), followed by DNA purification with phenol and phenol-chloroform-isoamyl alcohol $(25: 24: 1)$ extraction and ethanol precipitation in $0.3 \mathrm{M}$ sodium acetate ( $\mathrm{pH} 4.6)$.

2.2. PCR Amplification of HHV8 ORF26. The HHV8 ORF26 was amplified by nested PCR using oligoprimers and reaction conditions previously described $[31,32]$. In particular, rightward ORF26 has been amplified with outer oligonucleotides LGH2574L (5'-CAGAAACAGGGCTAGGTAC$\left.3^{\prime}\right)$ and LGH2575R ( $5^{\prime}$-GTGCTTGACGATCTGTCC-3' $)$ and with inner oligonucleotides SJF $\left(5^{\prime}\right.$-CTATCTTCAGAGTCTCAG- $3^{\prime}$ ) and SJR ( $5^{\prime}$-TAGGTACACACAATTTTG- $\left.{ }^{\prime}\right)$; leftward ORF26 has been amplified with outer oligonucleotides LGH1701R $\left(5^{\prime}\right.$-GGATCCCTCTGACAACC- $\left.3^{\prime}\right)$ and SJ2R ( $5^{\prime}$-GCCAAGATTAAATATAGAACTGAG- $\left.3^{\prime}\right)$ and inner oligonucleotides LGH1701R and SJ1R (5'-AATATAGAACTGAGACTCTGAAG-3') (Table 1). PCR amplification reactions were performed in $50 \mu \mathrm{L}$ reaction mixture containing 100 to $300 \mathrm{ng}$ of target DNA, 5 pmol of each primer, $2.5 \mathrm{mM} \mathrm{MgCl}_{2}, 50 \mu \mathrm{M}$ of each dNTP, and $5 \mu \mathrm{L}$ Hot Master buffer and 2.5 U of Hot Master Taq DNA Polymerase (5 Prime $\mathrm{GmbH}$, Hamburg, Germany). DNA was amplified in a Perkin-Elmer GeneAmp PCR System 9700 thermal cycler with the following steps: an initial 2 min denaturation at $94^{\circ} \mathrm{C}$, followed by 45 amplification cycles of $55^{\circ} \mathrm{C}$ for $45 \mathrm{sec}, 68^{\circ} \mathrm{C}$ for $1 \mathrm{~min}, 94^{\circ} \mathrm{C}$ for $15 \mathrm{sec}$, and a $5 \mathrm{~min}$ final elongation at $68^{\circ} \mathrm{C}$. A reaction mixture containing genomic DNA, extracted from NIH 3T3 murine cell line, was used as negative control and was included in every set of 5 clinical specimens. All HHV8 amplimers were subjected to bidirectional direct sequencing analysis.

2.3. HHV8 Real Time PCR. A SYBR Green real time PCR method was used to determine HHV8 viral load in all DNA samples. Specially, oligoprimers ORF26LR1F1 ( $5^{\prime}$-GCAGTATCTATCCAAGTG- $\left.3^{\prime}\right)$ and ORF26LR2R2 ( $5^{\prime}$ ACAGATCGTCAAGCA- $3^{\prime}$ ) producing a $434 \mathrm{bp}$ product were designed with Beacon Designer software (Premier Biosoft) and used for real time PCR (Table 1). HHV8 viral load quantization was performed in the Bio-Rad CFX96 real time PCR Detection System using 300 ng of template DNA, $12.5 \mu \mathrm{L}$ of iQ SYBR Green supermix (Bio Rad), and $5 \mathrm{pmol}$ each of forward and reverse primers in a final volume of $25 \mu \mathrm{L}$. Thermal cycling consisted of a denaturation step at $95^{\circ} \mathrm{C}$ for $3 \mathrm{~min}$, followed by 50 cycles of $55^{\circ} \mathrm{C}$ annealing for $30 \mathrm{~s}, 72^{\circ} \mathrm{C}$ extension for $30 \mathrm{~s}$, and $95^{\circ} \mathrm{C}$ denaturation for $30 \mathrm{~s}$. A standard curve was constructed using serial dilutions (1.0 to $10^{7}$ copies of BCBL1 cell line, containing 70 copies per cell of HHV8 DNA). Three replicates were performed for each sample and real time PCR data were analyzed using BioRad CFX manager software. The averaged copy numbers in samples were calculated according to the standard curve and were represented as copies of viral DNA per $10^{5}$ cells. The amount of human genomic DNA in each sample was also determined by real time PCR targeting human $\beta$ globin gene (GH20, $5^{\prime}$-GAAGAGCCAAGGACAGGTAC-3', and PC04, 5'-CAACTTCATCCACGTTCACC- $3^{\prime}$ ) and the quantification of human $\beta$-globin gene was used to normalize the target DNA.

2.4. Nucleotide Sequencing and Phylogenetic Analysis. Aliquots of HHV8 PCR amplified products were subjected to bidirectional direct sequencing analysis by Eurofins Genomics (Milan, Italy) using the fluorescent dye terminator technology and ABI 3730 DNA sequencers (Applied BioSystems, Foster City, CA). This Sanger based technique 
TABLE 1: PCR primer sequences used to amplify HHV8 ORF26 regions by standard PCR and real time PCR.

\begin{tabular}{|c|c|c|c|c|c|c|}
\hline Method & Locus & Primer name & Sequences $\left(5^{\prime}-3^{\prime}\right)$ & Nucleotide position & Size & Reference \\
\hline \multirow{2}{*}{ PCR outer } & \multirow{2}{*}{ ORF26-3' } & LGH2575-R & GTGCTTGACGATCTGTCC & $47,638-47,655$ & $620 \mathrm{bp}$ & {$[30]$} \\
\hline & & LGH2574-L & CAGAAACAGGGCTAGGTAC & $48,239-48,257$ & & \\
\hline \multirow{2}{*}{ PCR inner } & \multirow{2}{*}{ ORF26-3' } & SJ-F & CTATCTTCAGAGTCTCAG & $47,844-47,861$ & $402 \mathrm{bp}$ & {$[31]$} \\
\hline & & SJ-R & TAGGTACACACAATTTTG & $48,228-48,245$ & & \\
\hline \multirow{2}{*}{ PCR outer } & \multirow{2}{*}{ ORF26-5' } & LGH1701R & GGATCCCTCTGACAACC & $47,292-47,309$ & & \\
\hline & & SJ-R2 & GCCAAGATTAAATATAGAACTGAG & $47,857-47,880$ & $589 \mathrm{bp}$ & {$[31]$} \\
\hline \multirow{2}{*}{ PCR inner } & \multirow{2}{*}{ ORF26-5 } & LGH1701R & GGATCCCTCTGACAACC & $47,292-47,309$ & & \\
\hline & & SJ-R1 & AATATAGAACTGAGACTCTGAAG & $47,848-47,870$ & $579 \mathrm{bp}$ & [31] \\
\hline \multirow{2}{*}{ Real time PCR } & \multirow{2}{*}{ ORF26-3' } & ORF26LR1F1 & GCAGTATCTATCCAAGTG & $47,220-47,237$ & & \\
\hline & & ORF26LR2R2 & ACAGATCGTCAAGCA & $47,639-47,653$ & $434 \mathrm{bp}$ & This study \\
\hline
\end{tabular}

Nucleotide positions are given on the GenBank sequence number NC_009333.

is capable of detecting mixtures of viral variants when each variant represents $>15 \%$ of the viral population. Nucleotide sequences were edited with Chromas Lite 2.01 (http://www.technelysium.com.au/chromas.html) and converted to FASTA format. Multiple sequence alignments of HHV8 sequences from the present study and reference strains reported in the GenBank were performed with clustal W tool of MegAlign program of the Lasergene software (DNASTAR Inc., V7.0.0). Reference sequences for each HHV8 ORF26 subtype were DQ984689.1 (BCBLR, A/C), DQ984768.1 (HKS15, R), DQ984785.1 (431K, B1), DQ984789.1 (021K, B2), and DQ984759.1 (HKS21, J).

2.5. Statistical Analysis. Statistical analysis was performed with Epi Info 6 Statistical Analysis System software (Version 6.04b, 1997, Centers for Disease Control and Prevention, USA). Unpaired $t$-test was used for comparisons of continuous variables (i.e., age); Mantel-Haenszel corrected $\chi^{2}$ test and, where appropriate, two-sided Fisher's exact test were used for comparison of categorical data. Differences were considered to be statistically significant when $P$ values were less than 0.05 .

\section{Results}

Overall, HHV8 DNA has been detected in 14 out of $72(19.4 \%)$ conjunctiva neoplastic tissues and in 4 out of $60(6.7 \%)$ control tissues (Table 2). The prevalence of HHV8 DNA was found to be significantly different between cases and controls $(P=0.034)$. Following stratification of patients by HIV status the HHV8 DNA was found in 12 out of 48 (25\%) HIV-positive and in 2 out of 24 (8.3\%) HIV-negative conjunctiva neoplastic tissues (Table 3). The difference in HHV8 prevalence between these two groups was of borderline significance (Fisher's exact test two-tailed $P=0.120$ ), due to the limited sample size of controls with known HIV serostatus. HHV8 DNA has been identified in 4 out of 33 (12.1\%) PBMC samples of conjunctiva neoplasia diseased patients, for which conjunctiva biopsies were not available. The histology of the 72 conjunctival neoplasia patients identified 24 (33.3\%) lesions as invasive conjunctiva squamous carcinoma, $17(23.6 \%)$ as conjunctiva intraepithelial neoplasia grade 3 (CIN3), 16 (22.2\%) as CIN2,
TABLE 2: Distribution of known variables between conjunctival neoplasia cases and controls.

\begin{tabular}{lccc}
\hline & $\begin{array}{c}\text { Conjunctiva } \\
\text { neoplastic tissues } \\
N=72(\%)\end{array}$ & $\begin{array}{c}\text { Conjunctiva } \\
\text { control tissue* } \\
N=60(\%)\end{array}$ & $P$ value \\
\hline Sex & & & 0.724 \\
M & $31(43.1)$ & $24(40.0)$ & \\
F & $41(56.9)$ & $36(60.0)$ & \\
\hline Age & & & 0.584 \\
$\leq 30$ years & $31(43.1)$ & $23(38.3)$ & \\
$>30$ years & $41(56.9)$ & $37(61.7)$ & \\
\hline HHV8 PCR & & & 0.034 \\
Positive & $14(19.4)$ & $4(6.7)$ & \\
Negative & $58(80.5)$ & $56(93.3)$ & \\
\hline HIV serology ${ }^{\dagger}$ & & & \\
Positive & $48(66.7)$ & $15(38.5)$ & \\
Negative & $24(33.3)$ & $24(61.5)$ & \\
\hline
\end{tabular}

${ }^{*}$ Two pingueculae, 1 pterygium, and 1 papilloma of the conjunctiva were included in the control group.

${ }^{\dagger} 21$ control subjects with undetermined HIV serology were not included.

and $15(20.8 \%)$ as CIN1. The frequency of HHV8 infection among cases, grouped by histological types, was $20.8 \%(5 / 24)$ in the CSCC, $23.5 \%(4 / 17)$ in the CIN3, 25\% (4/16) in CIN2, and 6.7\% (1/15) in CIN1. Therefore, HHV8 detection frequency seems not associated with more advanced disease stages.

To quantify HHV8 viral load in conjunctiva DNA samples, serial dilution of DNA extracted from BCBL-1 cell line (range, $1 \times 10^{0}$ to $1 \times 10^{6}$ cells) in the background of human DNA was amplified with HHV8 and human $\beta$-globin oligonucleotides by real time PCR. The estimated HHV 8 copy number was 70 per BCBL-1 cell, which is in agreement with the value reported in the literature [33]. Of the 72 conjunctiva neoplasia DNA samples tested by real time PCR, 18 (25\%) were positive for HHV8 DNA with viral loads ranging from 1 to 400 copies $/ 10^{5}$ cells in different samples.

Amplimers obtained by nested PCR from 17 DNA samples were sequenced across the rightward and leftward 
TABLE 3: Distribution of HHV8 in HIV-positive and HIV-negative conjunctival neoplasia samples and controls.

\begin{tabular}{lccc}
\hline HIV status & $\begin{array}{c}\text { Conjunctiva } \\
\text { neoplastic tissues } \\
N(\%)\end{array}$ & $\begin{array}{c}\text { Conjunctiva } \\
\text { control tissue* } \\
N^{\dagger}(\%)\end{array}$ & $P$ value \\
\hline HIV positive & & & $0.347^{\ddagger}$ \\
HHV8-Pos & $12(25.0)$ & $2(13.3)$ & \\
HHV8-Neg & $36(75.0)$ & $13(86.7)$ & \\
\hline HIV negative & & & $1.000^{\ddagger}$ \\
HHV8-Pos & $2(8.3)$ & $1(4.2)$ & \\
HHV8-Neg & $22(91.7)$ & $23(95.8)$ & \\
\hline
\end{tabular}

${ }^{*}$ Two pingueculae, 1 pterygium, and 1 papilloma of the conjunctiva were included in the control group.

${ }^{\dagger} 21$ control subjects with undetermined HIV serology were not included.

${ }^{\ddagger}$ Fisher’s exact test, two-tailed.

ORF26 locus. All nucleotide differences between samples are described in Table 4. HHV8 ORF26 sequences mainly belong to B2 (10 out of $17,58.8 \%$ ), R (5 out of $17,29.4 \%$ ), B1 (1 out of 17, 5.9\%), and J (1 out of 17, 5.9\%) subtypes, following the nomenclature proposed by Zong et al. (2007) [30]. No multiple infections with different HHV8 variants were identified by nucleotide sequencing analysis.

\section{Discussion}

HHV8 has been clearly associated with proliferative disorders such as Kaposi sarcoma, primary effusion lymphoma, and multicentric Castleman's disease [10]. Several viral genes, such as v-GPCR, vIRF 1-4, vFLIP, and vIL-6, mainly expressed during the lytic phase of viral replication have been recognized as transforming factors acting through autocrine and paracrine mechanisms $[21,34]$. In fact, it has been shown that in Kaposi sarcoma tumors only few HHV8 infected cells undergo lytic reactivation and express a large number of viral proteins, which in turn contribute to angiogenesis in Kaposi tumors promoting the secretion of cellular or viral factors in a paracrine manner [21]. These paracrine proangiogenic properties raise the question whether HHV 8 might be implicated in the pathogenesis of vascular proliferative lesions other than Kaposi sarcoma.

In this study HHV8 sequences have been identified in $25 \%$ and $8 \%$ of HIV-positive and HIV-negative conjunctival neoplasia samples, respectively, suggesting a major effect of HIV-related immune suppression in HHV8 replication. The phylogenetic analysis of the conserved ORF26 amplimers indicated that subtypes $\mathrm{R}$ and $\mathrm{B} 2$ were the most common variants in conjunctiva samples, in agreement with previous results on $\mathrm{HHV} 8$ variant distribution in Ugandan Kaposi sarcoma cases [32]. Furthermore, the similar frequency rate of HHV8 positivity in invasive tumors compared to CIN2 and CIN3 lesions suggests that the virus might be involved in early phases of tumor development but is unlikely involved in tumor progression.

HHV8 loads have been evaluated in conjunctiva neoplasia samples and found to be in the range of 1 to 400 copies $/ 10^{5}$ cells. These values are comparable to those observed in PBMCs of HIV-related Kaposi sarcoma patients and are probably correlated to the immune status of subjects [35]. The results obtained so far are not sufficient to differentiate whether HHV8 has a direct role in the development of conjunctival carcinoma or is a bystander vehiculated by infected PBMCs in the high vascularized conjunctival lesions. However, in both cases it is possible to postulate a paracrine effect of the viral products enhancing angiogenesis and tumorigenesis in conjunctival mucosa.

The presence of HHV8 DNA has been investigated in several other disorders with controversial results. Nishimoto et al. identified HHV8 DNA sequences in a variable fraction of skin lesions such as Bowen's disease, actinic keratoses, leukoplakia, Paget's disease, melanoma, neurofibroma, and chronic dermatitis [36]. However, several other studies failed to confirm such association $[37,38]$.

McDonagh et al. described the presence of HHV8 DNA sequences in vascular proliferations including angiosarcomas (29\%) and haemangiomas (5\%) [39]. However, Lebbe et al. reported no association between HHV8 and non-Kaposi sarcoma vascular lesions in their patients [40].

More recently, few studies reported the detection of low levels of HHV8 DNA in lymphoproliferative diseases such as large-plaque parapsoriasis and mycosis fungoides [41, 42], but not confirmed in other studies [43-45]. Kreuter et al. hypothesized that this association may depend on high HHV8 seroprevalence in some geographic regions or HHV8 reactivation in immune compromised patients [42].

Moreover, Nalwoga et al. have recently shown that in Uganda, where malaria is highly endemic, the positivity for malaria antibodies is strongly associated with HHV8 seropositivity suggesting that malaria exposure may facilitate HHV8 reactivation, viral transmission, and related diseases [46].

Seroprevalence of HHV8 in Uganda is very high, ranging from $36 \%$ to $60 \%$ in the general population [47-49]. More recently high prevalence of HHV8 DNA has been detected in the plasma of HHV8 seropositive Ugandan subjects enrolled in a HIV/AIDS survey [26]. In their study, Shebl et al. found plasma viral DNA in $14 \%$ of HHV8 seropositive and $2 \%$ of HHV8 seronegative subjects suggesting that replicating virus is very common in the blood of Ugandan subjects, where HHV8 infection and Kaposi sarcoma are endemic.

This study has several limitations including the small sample size of controls with known HIV serostatus and the lack of material to evaluate HHV8 mRNA levels in conjunctiva samples. However this is the first study designed to systematically detect HHV8 DNA sequences in conjunctiva neoplasia at different grade of malignancy and the obtained results warrant further epidemiological and molecular studies.

\section{Conclusions}

In conclusion, HHV8 DNA sequences are detected in a significant fraction of HIV-positive conjunctival neoplasia cases from Uganda. The results obtained so far are not sufficient to determine whether HHV8 is a bystander vehiculated 
TABLE 4: Nucleotide changes identifying distinct subgroups of HHV8 genomes within the ORF26 gene locus. Dashes indicate identities to the prototype. Absence of genetic variations relative to the references is marked with dashes, whereas presence of variant nucleotides is indicated by the nucleotide corresponding letter. An empty space indicates sequence not available. $\wedge$ indicates nucleotide insertion; $\delta$ indicates nucleotide deletion. The numbering system conforms to that used by Tornesello et al. [32].

\begin{tabular}{|c|c|c|c|c|c|c|c|c|c|c|c|c|c|c|c|c|c|c|c|c|c|c|c|c|c|c|}
\hline \multirow{4}{*}{$\begin{array}{l}\text { Sample } \\
\text { name }\end{array}$} & & & 1 & 1 & 1 & 1 & 1 & 1 & 1 & 1 & 1 & 1 & 1 & 1 & 1 & 1 & 1 & 1 & 1 & 1 & 1 & 1 & 1 & 1 & 1 & \multirow{4}{*}{$\begin{array}{c}\text { ORF26 } \\
\text { class }\end{array}$} \\
\hline & 7 & 9 & 0 & 0 & 0 & 1 & 1 & 1 & 1 & 1 & 1 & 2 & 4 & 5 & 5 & 5 & 5 & 5 & 7 & 7 & 7 & 7 & 8 & 8 & 8 & \\
\hline & 3 & 8 & 3 & 5 & 8 & 2 & 3 & 3 & 4 & 5 & 7 & 0 & 9 & 4 & 6 & 6 & 6 & 9 & 1 & 2 & 5 & 9 & 0 & 1 & 2 & \\
\hline & 3 & 1 & 2 & 5 & 6 & 2 & 2 & 9 & 1 & 8 & 7 & 6 & 0 & 5 & 2 & 8 & 9 & 4 & 7 & 3 & 4 & 5 & 2 & 6 & 5 & \\
\hline BCBLR & $\mathrm{G}$ & $\mathrm{T}$ & $\mathrm{C}$ & G & $\mathrm{C}$ & $\mathrm{G}$ & $\mathrm{A}$ & $\mathrm{A}$ & $\mathrm{A}$ & $\mathrm{C}$ & $\mathrm{C}$ & $\mathrm{G}$ & $\mathrm{G}$ & $\mathrm{C}$ & $\wedge$ & $\mathrm{G}$ & $\mathrm{G}$ & $\mathrm{G}$ & $\mathrm{C}$ & $\mathrm{C}$ & $\mathrm{C}$ & $\mathrm{G}$ & G & $\mathrm{T}$ & $\mathrm{G}$ & $\mathrm{A} / \mathrm{C}$ \\
\hline HKS15 & & $\mathrm{C}$ & - & - & $\mathrm{T}$ & - & - & $\mathrm{C}$ & - & - & - & - & $\mathrm{T}$ & - & 0 & $\delta$ & $\delta$ & $\mathrm{T}$ & $\mathrm{T}$ & - & - & - & - & - & - & $\mathrm{R}$ \\
\hline CIN3.110 & - & $\mathrm{C}$ & - & - & $\mathrm{T}$ & - & - & $\mathrm{C}$ & - & - & - & - & $\mathrm{T}$ & - & & & & & & & & & & & & $\mathrm{R}$ \\
\hline CIN3.179 & - & $\mathrm{C}$ & - & - & $\mathrm{T}$ & - & - & $\mathrm{C}$ & - & - & - & - & $\mathrm{T}$ & - & & & & & & & & & & & & $\mathrm{R}$ \\
\hline CIN2.136 & - & $\mathrm{C}$ & - & - & $\mathrm{T}$ & - & - & $\mathrm{C}$ & - & - & - & - & $\mathrm{T}$ & - & & & & & & & & & & & & $\mathrm{R}$ \\
\hline CIN2.169 & - & C & - & - & $\mathrm{T}$ & - & - & C & - & - & - & - & $\mathrm{T}$ & - & 0 & $\delta$ & $\delta$ & $\mathrm{T}$ & $\mathrm{T}$ & - & - & - & - & - & - & $\mathrm{R}$ \\
\hline CIN1.173 & - & $\mathrm{C}$ & - & - & $\mathrm{T}$ & - & - & $\mathrm{C}$ & - & - & - & - & $\mathrm{T}$ & - & 0 & $\delta$ & $\delta$ & $\mathrm{T}$ & $\mathrm{T}$ & - & - & - & - & - & - & $\mathrm{R}$ \\
\hline $431 \mathrm{~K}$ & & $\mathrm{C}$ & - & - & - & - & G & $\mathrm{C}$ & - & - & - & - & - & - & 0 & $\mathrm{~T}$ & $\mathrm{~A}$ & - & - & $\mathrm{T}$ & - & $\mathrm{C}$ & - & $\mathrm{C}$ & $\mathrm{A}$ & $\mathrm{B} 1$ \\
\hline SCC.193 & - & $\mathrm{C}$ & - & - & - & - & $\mathrm{G}$ & $\mathrm{C}$ & - & - & - & - & - & - & 0 & $\mathrm{~T}$ & $\mathrm{~A}$ & - & - & $\mathrm{T}$ & - & $\mathrm{C}$ & - & $\mathrm{C}$ & $\mathrm{A}$ & $\mathrm{B} 1$ \\
\hline $021 \mathrm{~K}$ & & $\mathrm{C}$ & $\mathrm{A}$ & - & - & - & G & $\mathrm{C}$ & - & - & - & - & - & - & 0 & $\mathrm{~T}$ & $\mathrm{~A}$ & - & - & $\mathrm{T}$ & - & $\mathrm{C}$ & - & $\mathrm{C}$ & $\mathrm{A}$ & B2 \\
\hline SCC.108 & - & $\mathrm{C}$ & A & - & - & - & G & $\mathrm{C}$ & - & - & - & - & - & - & 0 & $\mathrm{~T}$ & A & - & - & $\mathrm{T}$ & - & $\mathrm{C}$ & - & $\mathrm{C}$ & A & B2 \\
\hline SCC.144 & - & C & A & - & - & - & G & C & - & - & - & - & - & - & & & & & & & & & & & & B2 \\
\hline SCC. 218 & - & C & A & - & - & - & G & $\mathrm{C}$ & - & - & - & - & - & - & & & & & & & & & & & & B2 \\
\hline CIN3.99 & - & $\mathrm{C}$ & A & - & - & - & G & $\mathrm{C}$ & - & - & - & - & - & - & & & & & & & & & & & & B2 \\
\hline CIN3.167 & - & $\mathrm{C}$ & A & - & - & - & G & $\mathrm{C}$ & - & - & - & - & - & - & & & & & & & & & & & & B2 \\
\hline CIN2.138 & - & $\mathrm{C}$ & A & - & - & - & G & $\mathrm{C}$ & - & - & - & - & - & - & & & & & & & & & & & & $\mathrm{B} 2$ \\
\hline CIN2.143 & - & $\mathrm{C}$ & A & - & - & - & G & $\mathrm{C}$ & - & - & - & - & - & - & 0 & $\mathrm{~T}$ & A & - & - & $\mathrm{T}$ & - & $\mathrm{C}$ & - & C & A & B2 \\
\hline CTR.142 & - & $\mathrm{C}$ & A & - & - & - & G & $\mathrm{C}$ & - & - & - & - & - & - & & & & & & & & & & & & $\mathrm{B} 2$ \\
\hline CTR.143 & - & $\mathrm{C}$ & A & - & - & - & G & $\mathrm{C}$ & - & - & - & - & - & - & & & & & & & & & & & & $\mathrm{B} 2$ \\
\hline CTR.149 & - & $\mathrm{C}$ & A & - & - & - & G & $\mathrm{C}$ & - & - & - & - & - & - & & & & & & & & & & & & B2 \\
\hline HKS21 & & C & A & $\mathrm{T}$ & - & - & G & $\mathrm{C}$ & - & - & & - & - & - & 0 & - & - & - & - & - & - & - & - & - & - & $\mathrm{J}$ \\
\hline SCC.142 & - & $\mathrm{C}$ & $\mathrm{A}$ & $\mathrm{T}$ & - & - & G & $\mathrm{C}$ & - & - & - & - & - & - & & & & & & & & & & & & $\mathrm{J}$ \\
\hline
\end{tabular}

by infected PBMCs in the high vascularized conjunctival lesions or is able to infect cells populating the conjunctiva. Further studies are needed to determine if the expression and secretion of viral and human inflammatory factors, such as vIL6 and the human homologue, contribute to angiogenesis and tumorigenesis of conjunctival neoplasia in a paracrine fashion.

\section{Abbreviations}

HHV8: Human herpesvirus type 8

CIN: Conjunctival intraepithelial neoplasia

CSCC: Conjunctival squamous cell carcinoma

KS: $\quad$ Kaposi sarcoma

HIV: Human immunodeficiency virus.

\section{Conflict of Interests}

The authors declare that there is no conflict of interests regarding the publication of this paper.

\section{Acknowledgments}

The authors thank Dr. Sebastian Lucas for the histopathological characterization of all conjunctival biopsies analyzed in the study. This work was supported by grants from Ministero della Salute, Ricerca Corrente 2014 no. 2610139, and the ICSCWorld Laboratory (Project MCD-2/7).

\section{References}

[1] K. M. Waddell, S. Lewallen, S. B. Lucas, C. Atenyi-Agaba, C. S. Herrington, and G. Liomba, "Carcinoma of the conjunctiva and HIV infection in Uganda and Malawi," British Journal of Ophthalmology, vol. 80, no. 6, pp. 503-508, 1996.

[2] M. Guech-Ongey, E. A. Engels, J. J. Goedert, R. J. Biggar, and S. M. Mbulaiteye, "Elevated risk for squamous cell carcinoma of the conjunctiva among adults with AIDS in the United States," International Journal of Cancer, vol. 122, no. 11, pp. 2590-2593, 2008.

[3] E. Chokunonga, M. Z. Borok, Z. M. Chirenje, A. M. Nyakabau, and D. M. Parkin, "Trends in the incidence of cancer in the 
black population of Harare, Zimbabwe 1991-2010," International Journal of Cancer, vol. 133, no. 3, pp. 721-729, 2013.

[4] S. M. Mbulaiteye, K. Bhatia, C. Adebamowo, and A. J. Sasco, "HIV and cancer in Africa: mutual collaboration between HIV and cancer programs may provide timely research and public health data," Infectious Agents and Cancer, vol. 6, no. 1, article 16, 2011.

[5] S. N. Akarolo-Anthony, L. D. Maso, F. Igbinoba, S. M. Mbulaiteye, and C. A. Adebamowo, "Cancer burden among HIVpositive persons in Nigeria: preliminary findings from the Nigerian AIDS-cancer match study," Infectious Agents and Cancer, vol. 9, no. 1, article 1, 2014.

[6] H. R. Wabinga, S. Nambooze, P. M. Amulen, C. Okello, L. Mbus, and D. M. Parkin, "Trends in the incidence of cancer in Kampala, Uganda 1991-2010," International Journal of Cancer, vol. 135, no. 2, pp. 432-439, 2014.

[7] M. L. Tornesello, M. L. Duraturo, K. M. Waddell et al., "Evaluating the role of human papillomaviruses in conjunctival neoplasia," British Journal of Cancer, vol. 94, no. 3, pp. 446-449, 2006.

[8] C. Ateenyi-Agaba, E. Weiderpass, M. Tommasino et al., "Papillomavirus infection in the conjunctiva of individuals with and without AIDS: an autopsy series from Uganda," Cancer Letters, vol. 239, no. 1, pp. 98-102, 2006.

[9] C. Ateenyi-Agaba, S. Franceschi, F. Wabwire-Mangen et al., "Human papillomavirus infection and squamous cell carcinoma of the conjunctiva," British Journal of Cancer, vol. 102, no. 2, pp. 262-267, 2010.

[10] F. M. Buonaguro, M. L. Tornessello, L. Buonaguro et al., "Kaposi's sarcoma: aetiopathogenesis, histology and clinical features," Journal of the European Academy of Dermatology and Venereology, vol. 17, no. 2, pp. 138-154, 2003.

[11] Y. Chang, E. Cesarman, M. S. Pessin et al., "Identification of herpesvirus-like DNA sequences in AIDS-associated Kaposi's sarcoma," Science, vol. 266, no. 5192, pp. 1865-1869, 1994.

[12] E. Cesarman, Y. Chang, P. S. Moore, J. W. Said, and D. M. Knowles, "Kaposi's sarcoma-associated herpesvirus-like DNA sequences in AIDS-related body-cavity-based lymphomas," The New England Journal of Medicine, vol. 332, no. 18, pp. 1186-1191, 1995.

[13] J. Soulier, L. Grollet, E. Oksenhendler et al., "Kaposi's sarcomaassociated herpesvirus-like DNA sequences in multicentric Castleman's disease," Blood, vol. 86, no. 4, pp. 1276-1280, 1995.

[14] M. Bhutani, M. N. Polizzotto, T. S. Uldrick, and R. Yarchoan, "Kaposi sarcoma-associated herpesvirus-associated malignancies: epidemiology, pathogenesis, and advances in treatment," Seminars in Oncology, vol. 42, no. 2, pp. 223-246, 2015.

[15] R. A. Schwartz, G. Micali, M. R. Nasca, and L. Scuderi, "Kaposi sarcoma: a continuing conundrum," Journal of the American Academy of Dermatology, vol. 59, no. 2, pp. 179-206, 2008.

[16] L. Pantanowitz and B. J. Dezube, "Kaposi sarcoma in unusual locations," BMC Cancer, vol. 8, article 190, 2008.

[17] E. Ruocco, V. Ruocco, M. L. Tornesello, A. Gambardella, R. Wolf, and F. M. Buonaguro, "Kaposi's sarcoma: etiology and pathogenesis, inducing factors, causal associations, and treatments: facts and controversies," Clinics in Dermatology, vol. 31, no. 4, pp. 413-422, 2013.

[18] J. D. Shuler, G. N. Holland, S. A. Miles, B. J. Miller, and I. Grossman, "Kaposi sarcoma of the conjunctiva and eyelids associated with the acquired immunodeficiency syndrome," Archives of Ophthalmology, vol. 107, no. 6, pp. 858-862, 1989.
[19] E. A. Mesri, E. Cesarman, and C. Boshoff, "Kaposi's sarcoma and its associated herpesvirus," Nature Reviews Cancer, vol. 10, no. 10, pp. 707-719, 2010.

[20] E. A. Mesri, M. A. Feitelson, and K. Munger, "Human viral oncogenesis: a cancer hallmarks analysis," Cell Host and Microbe, vol. 15, no. 3, pp. 266-282, 2014.

[21] S. Gramolelli and T. F. Schulz, "The role of Kaposi sarcomaassociated herpesvirus in the pathogenesis of Kaposi sarcoma," The Journal of Pathology, vol. 235, no. 2, pp. 368-380, 2014.

[22] T. S. Uldrick, V. Wang, D. O'Mahony et al., "An interleukin6-related systemic inflammatory syndrome in patients coinfected with kaposi sarcoma-associated herpesvirus and HIV but without Multicentric Castleman disease," Clinical Infectious Diseases, vol. 51, no. 3, pp. 350-358, 2010.

[23] W. Wu, J. Vieira, N. Fiore et al., "KSHV/HHV-8 infection of human hematopoietic progenitor (CD34+) cells: persistence of infection during hematopoiesis in vitro and in vivo," Blood, vol. 108, no. 1, pp. 141-151, 2006.

[24] B. Chandran, "Early events in Kaposi's sarcoma-associated herpesvirus infection of target cells," Journal of Virology, vol. 84, no. 5, pp. 2188-2199, 2010.

[25] M. Corbellino, L. Poirel, G. Bestetti et al., "Restricted tissue distribution of extralesional Kaposi's sarcoma-associated herpesvirus-like DNA sequences in AIDS patients with Kaposi's sarcoma," AIDS Research and Human Retroviruses, vol. 12, no. 8, pp. 651-657, 1996.

[26] F. M. Shebl, B. Emmanuel, L. Bunts et al., "Population-based assessment of kaposi sarcoma-associated herpesvirus DNA in plasma among Ugandans," Journal of Medical Virology, vol. 85, no. 9, pp. 1602-1610, 2013.

[27] J. Min and D. A. Katzenstein, "Detection of Kaposi's sarcomaassociated herpesvirus in peripheral blood cells in human immunodeficiency virus infection: association with Kaposi's sarcoma, CD4 cell count, and HIV RNA levels," AIDS Research and Human Retroviruses, vol. 15, no. 1, pp. 51-55, 1999.

[28] D. V. Ablashi, L. G. Chatlynne, J. E. Whitman Jr., and E. Cesarman, "Spectrum of Kaposi's sarcoma-associated herpesvirus, or human herpesvirus 8, diseases," Clinical Microbiology Reviews, vol. 15, no. 3, pp. 439-464, 2002.

[29] M. L. Tornesello, K. M. Waddell, M. L. Duraturo et al., “TP53 codon 72 polymorphism and risk of conjunctival squamous cell carcinoma in Uganda," Cancer Detection and Prevention, vol. 29, no. 6, pp. 501-508, 2005.

[30] J.-C. Zong, H. Kajumbula, W. Boto, and G. S. Hayward, "Evaluation of global clustering patterns and strain variation over an extended ORF26 gene locus from Kaposi's sarcoma herpesvirus," Journal of Clinical Virology, vol. 40, no. 1, pp. 1925, 2007.

[31] S. Jalilvand, M. L. Tornesello, F. M. Buonaguro et al., "Molecular epidemiology of human herpesvirus 8 variants in Kaposi's sarcoma from Iranian patients," Virus Research, vol. 163, no. 2, pp. 644-649, 2012.

[32] M. L. Tornesello, B. Biryahwaho, R. Downing et al., "Human herpesvirus type 8 variants circulating in Europe, Africa and North America in classic, endemic and epidemic Kaposi's sarcoma lesions during pre-AIDS and AIDS era," Virology, vol. 398 , no. 2, pp. 280-289, 2010.

[33] F. Lallemand, N. Desire, W. Rozenbaum, J.-C. Nicolas, and V. Marechal, "Quantitative analysis of human herpesvirus 8 viral load using a real-time PCR assay," Journal of Clinical Microbiology, vol. 38, no. 4, pp. 1404-1408, 2000. 
[34] Y. B. Choi and J. Nicholas, "Autocrine and paracrine promotion of cell survival and virus replication by human herpesvirus 8 chemokines," Journal of Virology, vol. 82, no. 13, pp. 6501-6513, 2008.

[35] A.-G. Marcelin, I. Gorin, P. Morand et al., "Quantification of Kaposi's sarcoma-associated herpesvirus in blood, oral mucosa, and saliva in patients with Kaposi's sarcoma," AIDS Research and Human Retroviruses, vol. 20, no. 7, pp. 704-708, 2004.

[36] S. Nishimoto, R. Inagi, K. Yamanishi, K. Hosokawa, M. Kakibuchi, and K. Yoshikawa, "Prevalence of human herpesvirus-8 in skin lesions," British Journal of Dermatology, vol. 137, no. 2, pp. 179-184, 1997.

[37] C. Boshoff, S. Talbot, M. Kennedy, J. O’Leary, T. Schulz, and Y. Chang, "HHV8 and skin cancers in immunosuppressed patients," The Lancet, vol. 347, no. 8997, pp. 338-339, 1996.

[38] S. Kohler, O. W. Kamel, P. P. Chang, and B. R. Smoller, "Absence of human herpesvirus 8 and Epstein-Barr virus genome sequences in cutaneous epithelial neoplasms arising in immunosuppressed organ-transplant patients," Journal of Cutaneous Pathology, vol. 24, no. 9, pp. 559-563, 1997.

[39] D. P. McDonagh, J. Liu, M. J. Gaffey, L. J. Layfield, N. Azumi, and S. T. Traweek, "Detection of Kaposi's sarcoma-associated herpesvirus-like DNA sequence in angiosarcoma," The American Journal of Pathology, vol. 149, no. 4, pp. 1363-1368, 1996.

[40] C. Lebbe, C. Pellet, B. Flageul et al., "Sequences of human herpesvirus 8 are not defected in various non-Kaposi sarcoma vascular lesions," Archives of Dermatology, vol. 133, no. 7, pp. 919-920, 1997.

[41] E. Trento, C. Castilletti, C. Ferraro et al., "Human herpesvirus 8 infection in patients with cutaneous lymphoproliferative diseases," Archives of Dermatology, vol. 141, no. 10, pp. 1235-1242, 2005.

[42] A. Kreuter, S. Bischoff, M. Skrygan et al., "High association of human herpesvirus 8 in large-plaque parapsoriasis and mycosis fungoides," Archives of Dermatology, vol. 144, no. 8, pp. 10111016, 2008.

[43] R. Pawson, D. Catovsky, and T. F. Schulz, "Lack of evidence of HHV-8 in mature T-cell lymphoproliferative disorders," The Lancet, vol. 348, no. 9039, pp. 1450-1451, 1996.

[44] E. Nagore, E. Ledesma, C. Collado, V. Oliver, A. Pérez-Pérez, and A. Aliaga, "Detection of Epstein-Barr virus and human herpesvirus 7 and 8 genomes in primary cutaneous T- and Bcell lymphomas," British Journal of Dermatology, vol. 143, no. 2, pp. 320-323, 2000.

[45] W. Kempf, M. E. Kadin, H. Kutzner et al., "Lymphomatoid papulosis and human herpesviruses-a PCR-based evaluation for the presence of human herpesvirus 6, 7 and 8 and related herpesviruses," Journal of Cutaneous Pathology, vol. 28, no. 1, pp. 29-33, 2001.

[46] A. Nalwoga, S. Cose, K. Wakeham et al., "Association between malaria exposure and Kaposi's sarcoma-associated herpes virus seropositivity in Uganda," Tropical Medicine \& International Health, vol. 20, no. 5, pp. 665-672, 2015.

[47] B. Biryahwaho, S. C. Dollard, R. M. Pfeiffer et al., "Sex and geographic patterns of human herpesvirus 8 infection in a nationally representative population-based sample in Uganda," The Journal of Infectious Diseases, vol. 202, no. 9, pp. 1347-1353, 2010.

[48] C. Mbondji-Wonje, V. Ragupathy, S. Lee, O. Wood, B. Awazi, and I. K. Hewlett, "Seroprevalence of human herpesvirus-8 in HIV-1 infected and uninfected individuals in Cameroon," Viruses, vol. 5, no. 9, pp. 2253-2259, 2013.
[49] S. M. Mbulaiteye, R. J. Biggar, R. M. Pfeiffer et al., "Water, socioeconomic factors, and human herpesvirus 8 infection in Ugandan children and their mothers," Journal of Acquired Immune Deficiency Syndromes, vol. 38, no. 4, pp. 474-479, 2005. 


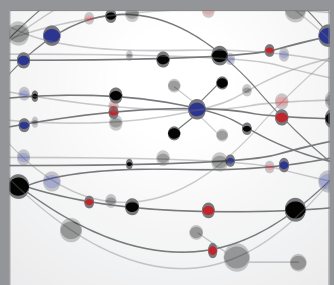

The Scientific World Journal
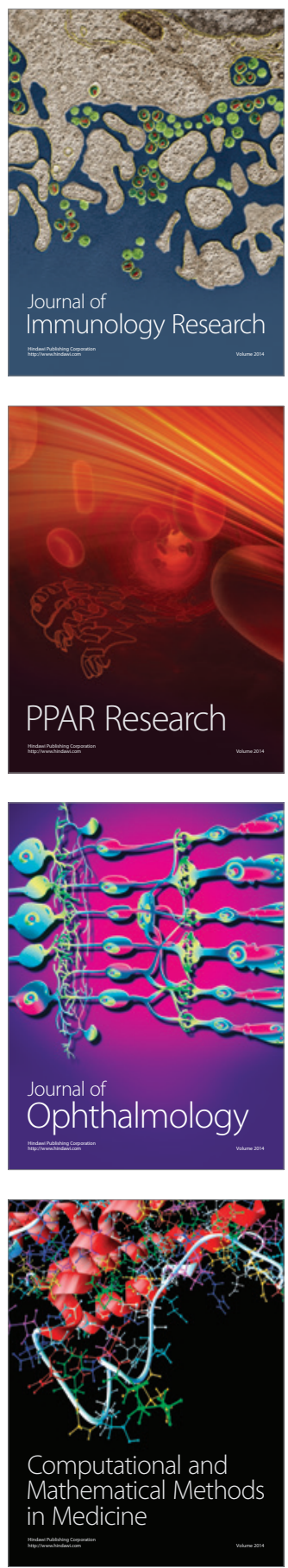

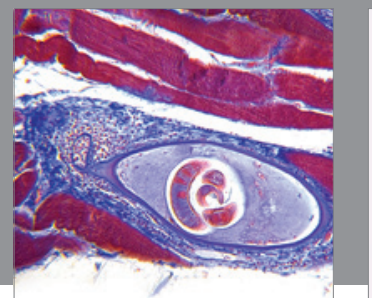

Gastroenterology

Research and Practice
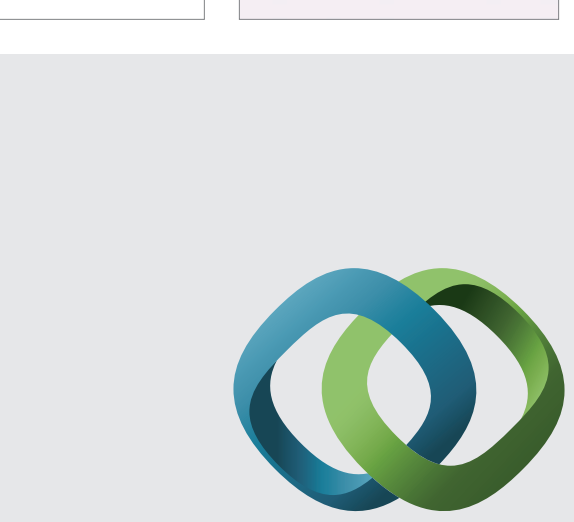

\section{Hindawi}

Submit your manuscripts at

http://www.hindawi.com
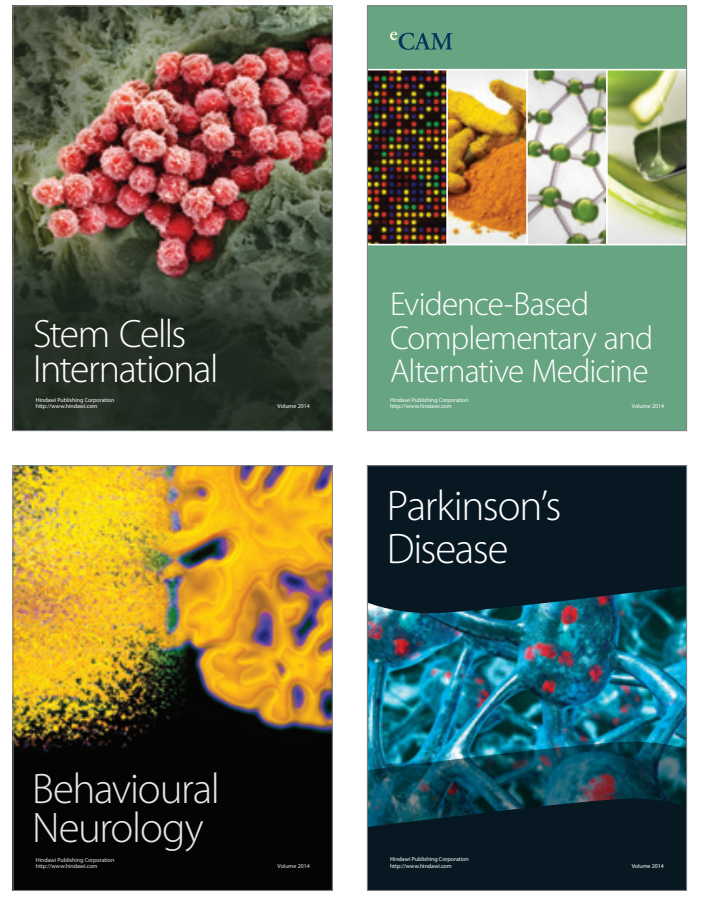
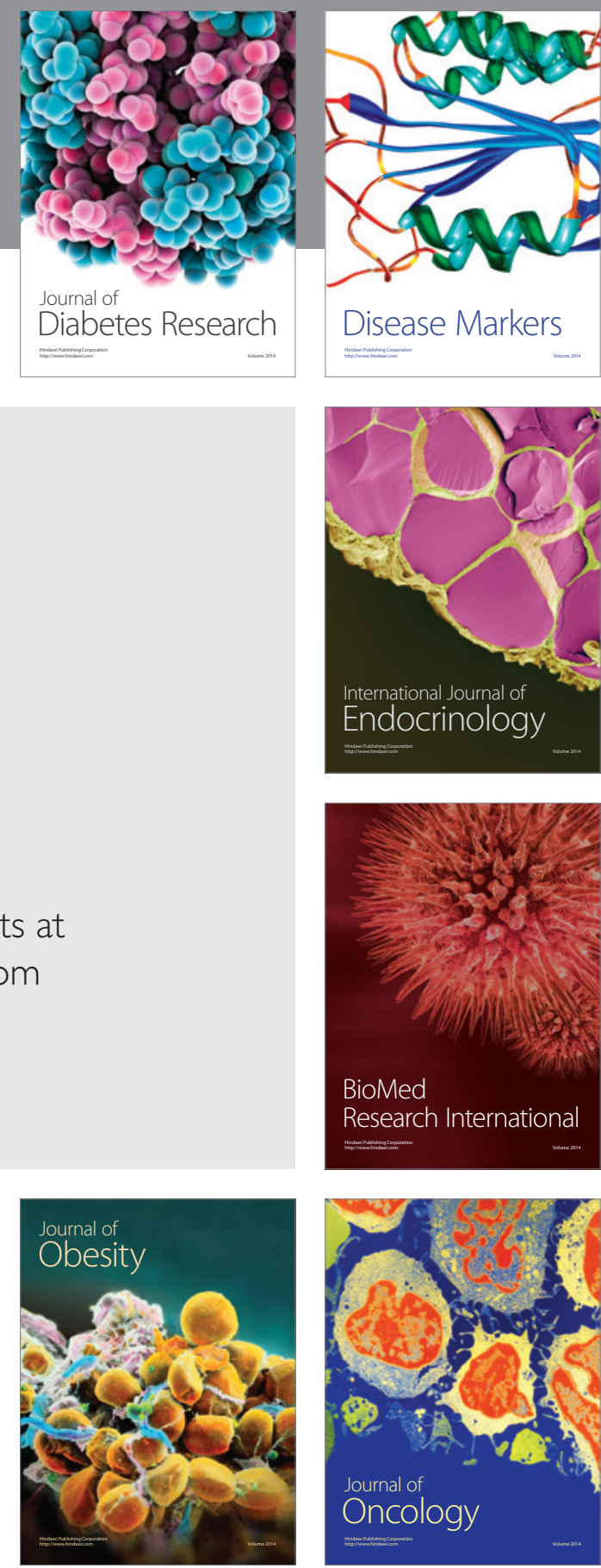

Disease Markers
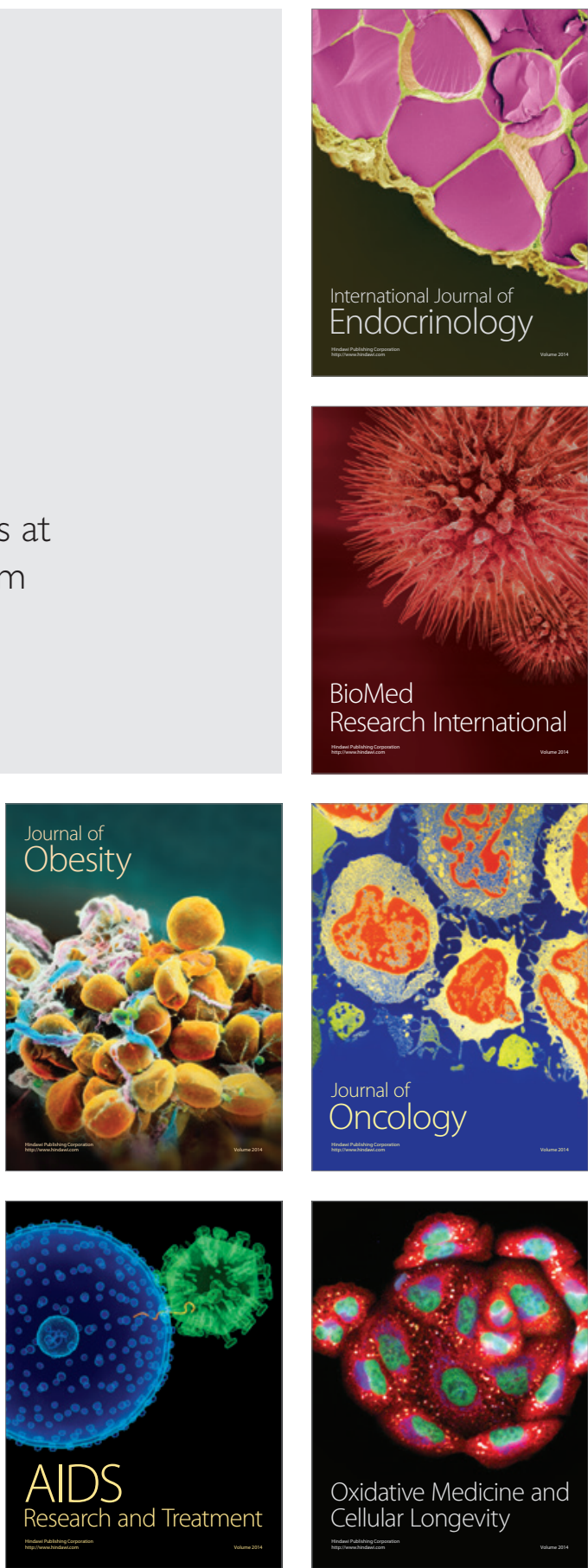